\title{
The Development of FTA Rules of Origin Functions
}

\author{
Xinxuan Cheng \\ School of Management, Hebei University \\ Baoding 071002, Hebei, China \\ E-mail: cheng_xinxuan@126.com
}

\begin{abstract}
The rules of origin derived from the international trade needs of country trade statistics. When a government determined the supply and demand sources of imports and exports, they needed to clear the meaning of origin. For a large trade country, its customs levels differed from the country. So when imported the goods, the first was to discern the source of goods, then can accurately provide the appropriate treatment of the goods. It's also the need to balance international trade. From this, the rules of origin initially were the technical aspects of international trade. With the development of liberalization of international trade and the tariff levels gradually reduced between countries, the use of non-tariff barriers was limited. Rules of origin's impact on trade structure and resource allocation became more and more prominent, which had evolved into a hidden trade protection tool. With the deepening of international economic exchange, the application of rules of origin had expanded from the original customs technical problems to the country quotas, anti-dumping and many other fields. Also, it had become a powerful policy tool for implementing the trade protection, to some extent it had evolved into the discriminatory non-tariff barriers.
\end{abstract}

Keywords: FTA, Rules of origin, Function

\section{The original function of FTA rules of origin}

The functions of rules of origin in a country or a region first were for the need of origin marks, consumer interests protection and international trade statistics, which was a technology standard. Rules of origin may help the country clear the origin countries of consumption products, thus to make the right consuming decision and better safeguard the interests of consumers. For example, the U.S. Customs required that all imports with foreign origin must be marked and indicated the country of origin. Some commodities may be exempted from this requirement, but must indicate the country of origin on the outermost layer trademark. The free trade area rules of origin, compared to a country's rules of origin, apart from the above functions, there was still an important feature was to prevent trade deflection. The difference between the free trade area and customs union was that the free trade area members had the right to establish the external tariffs level, so external tariffs level of members varied. If there were no rules of origin, member states outside the region, in seek of maximum benefits, under the case of low transport costs, the inevitable choice for the export was to the countries with low tariffs, and enjoyed preferential treatments as well as exported to the destination country. Then emerging the trade deflection. The result of trade deflection may force the member countries to tariff war, competing to lower tariff levels, and at last arising zero tariffs. In order to prevent trade deflection, free trade area may formulate rules of origin, and this was the original function of FTA rules of origin.

\section{The cause of evolution of FTA rules of origin functions}

The function of a thing varied with the environment was an adaptive mutation. The functions of rules of origin also changed with the international economic environments. Its main cause of evolution was the rapid development of free trade area and requirements for new trade protection tools.

\subsection{The rapid development of FTA was the basis for evolution of rules of origin functions}

Over the last decade, the global regional economic cooperation organizations developed rapidly. According to World Bank report, by the end of 2004, the number of regional trade agreements notifying the WTO increased from 50 in the 90 's of 20th century to 230, an increase of nearly 5 times. In addition, 60 regional agreements were in different stages of negotiations, while a considerable number of regional agreements did not notify the WTO for various reasons. The development of regional trade changed the original pattern of world trade in a large extent, among which the trading volume between countries within the region at the end of 2004 accounted for $40 \%$ of the global trade. Another attention getting phenomenon was almost all countries have participated in at least one regional economic organization, some countries even participated in regional organizations in group. 
Developed countries had shown more "passion" on regional economic cooperation, an average of 13 agreements for every country. In addition, today's regional agreements, there were both across geographical regions agreements and regional agreements constituted by different levels of economic development countries. According to statistics, there were 45 developing countries or economies in transition countries had signed bilateral preferential trade agreements with the developed industrial countries, which mainly were countries in Eastern Europe, North Africa and Latin America.

Modern form of regional economic cooperation organizations had gone beyond the geographical proximity factor. Regional economic cooperation organizations established in 40's of the 20th century. At that time, geographical proximity and closer trade relations were two important factors constituted regional economic organizations. The regional economic organizations formed before the 90's of the 20th century showed an obvious characteristic of geographic proximity. But after that, the formation of regional economic organizations focused more on the tightness of the economy, beyond the geographical proximity factors, thus cross-regional trade agreements obtained rapid development. To October 2003, in all WTO member countries, there were 65 parties had signed or were in negotiations of cross-regional trade agreements, $10 \%$ of the cross-regional agreements were already in implementation.

The rapid increase of Free Trade Area number with the emergence of diverse regional models made rules of origin became very important for the free trade area. Decline of regional trade barriers as well as the use of non-tariff barriers restriction all made the choice of trade protection tools limited. However, on the basis of pursuit of regional economic and political interests, a new trade protection tool became necessary, and the rules of origin catered to this requirement, which evolved from a simple technology of the past to the trade policy.

\subsection{The integration of production network brought by the FTA made the rules of origin become more important}

Modern regional trade organizations greatly promoted the integration of regional production network. With the rapid development of regional economic organizations, different development levels countries had established close economic ties, and the number of intra-regional trade were expanded, trade structures had changed accordingly. First of all, in all regions, the trade of manufactured goods in developing countries accounted for a large proportions, in particular, the production chain formed by intermediate inputs had become very prominent. Second, the specialization of productions in developing countries was improved. In addition, foreign direct investments played an important role in promoting the regional integration processes. Such changes in the structure of intra-regional trade led to regional production networks showed different characteristics - the integration of production network.

The integration of production network meant that multilateral, complementary and cross-cutting of intra-regional industrial division. The so-called multilateral meant starting the division of labor between national economies, not only in the member countries within the region, but also in different regions. By the end of 2004, intra-regional trade accounted for $40 \%$ of world trade volume, the remaining $60 \%$ included the regional member countries and national economies outside the region. Particularly for East Asia, the trade volume between China and ASEAN were gradually increased, but the trade volume with the developed countries still accounted for a large proportion, which depended on the developed countries heavily. Similarly, the European Union and the North American Free Trade Area also focused on trade with countries outside the region. This trade structures made industry specialization not just a simple horizontal and vertical division, but with diverse and cross division forms.

\section{Insert Figures 1 and 2 Here}

Free Trade Area promoted integration of production network, had increased the degree of products specialization. The final completion of one product may involve a number of countries, which needed to be processed separately in many countries, and needed to specify the origin of products and met the need of protection for consumers and trade statistics. This strengthened the original functions of the rules of origin, and because of increased production dispersion, the standards of rules of origin needed to be very specific, thus detailed rules of origin may inevitably affect the strategic choice of manufacturers, and producing economic results, affecting the creation of region trade, trade diversion, finally may impact the region's overall welfare level.

\subsection{The demand for trade protection under the new situation}

So far, the multilateral trade negotiations have undergone nine rounds of negotiations. The tariffs in developed and developing countries have greatly reduced. Reduction in tariff levels between member states, and the restrictions use of non-tariff barriers are necessarily led to increase the flow of goods significantly as well as deepening the international trade liberalization, but the principle of supremacy of national interests did not 
eliminate the trade protection, it was the protection tool that should adapt to the new international situation.

At present, in multilateral trade agreements, the protection tools can be used in trades including anti-dumping, anti-circumvention and special safeguard measures. Among which, the anti-dumping measures, with the verification and determination were related to the standards of rules of origin. The implementation of anti-circumvention measures was also related to the origin of the product. Quotas and quantitative restrictions also had a direct relationship with the standards of rules of origin. Whether these trade protection measures can be real implemented was directly related to the rules of origin, the identification of their objects can be completely used by the government, making it a tool to realize their political and economic objectives. Many countries were abusing anti-dumping measures, making it a tool for trade protection. The rules of origin catered to the demand of politicians, become an important non-tariff barrier in nowadays' international trading system. The use of the rules of origin of a country or a region can protect its related industries, affecting the effectiveness of its resource allocation and trade structures.

\section{The new functions of FTA rules of origin}

With the rapid development of the free trade area and the new form appeared in regional agreements, the rules of origin in free trade areas had been endowed with new functions.

\subsection{Reflecting the regional member countries economic and political interests}

FTA rules of origin were used to determine whether the imports enjoy the preferential treatments. Rules of origin was not a manifestation of national interest, but the coordination between member states, determining according to the regional trade structure, industry advantages, which aimed at not only reflecting the economic interests between member countries, but also the whole regional economic interests. The closed internal free trade area was a regional organization "internal freedom and external protection", but with the reduction of barriers outside the region and the gradual elimination of non-tariff barriers, nothing but the rules of origin can be used as an important means of protection. Different regional economic organizations adopted different rules of origin to protect the region's economic interests. For example, one fourth of EU rules of origin adopted value content criteria, and the free trade agreements with South Africa limited a minimum standard of $15 \%$ and not applied to textiles and clothing. NAFTA had also adopted the value content standards, but calculation methods were different from the European Union and other free trade areas, the minimum was lowered compared to the EU, and not applied to milk and edible animal products. The textiles also had a minimum limit of 7\%. In Mercosur, there were no minimum content standards in Asia and Africa trade agreements, these different rules of origin all reflected the different characteristics of various regional industries and their protection levels. The rules of origin adopted the conditions such as limited the content of imported contents and value-added percentage, protected the intermediate inputs manufacturers with in the region effectively. Also increased the attractiveness of foreign investment and promoting regional economic development.

\subsection{Beyond the WTO rules}

Free trade area was a form of regional economic organization. It was compatible with the WTO. About its provisions there were full embodiments in Article 24 of the multilateral trade agreements. In recent years establishing a review mechanism in the WTO, but it was not truly implemented. Therefore, from the actual operation point of view, free trade areas had certain independence, rules of origin within the region was decided by the member countries within the region, free from the impact of the WTO. It was difficult to compare the provisions of the WTO and the Free Trade Area rules of origin, because the rules of origin in free trade area were very detailed, but the WTO rules of origin were only a matter of principle, and its main principle was "control the use of rules of origin". It seldom related to specific contents. This mechanism provided a relaxed environment for the rules of origin to protect the relative industries within the region. That's why the current rules of origin served as a hidden trade protection tool.

\subsection{The deepening mergence of rules of origin and the production stage}

The trade and financial globalization as well as the internationalization of production promoted the development of economic globalization. In which the internationalization of production was the most significant international phenomenon in the world economy, also the performance of deepening development of international relations. The main bodies of the internationalization of production were transnational corporations, by the organization of production, output the company's capital, technology and management experience in the world, forming the dominant international division. Different processes and links of a product were finished in different countries and regions. It established subsidiaries all around the world, closely combined the company's monopoly advantages with the local regional advantages. As Lake said in the "World Competitiveness Report" that"in the 
GATT framework, the company can set up factories in any country. Goods, services and capital could flow freely, nothing can prevent a company making full use of the comparative advantages of different countries. The whole world were a factory, each country had become a workshop."The internationalization of multinational companies promoted the transnational flow of production factors and goods, accelerated the liberalization of international trade. Among which, the multinational companies made the intermediate inputs trade accounted for $30 \%$ of manufacturing trade (Yeats, 2001). In 1999, the intermediate goods accounted for $93 \%$ of the exports of U.S. parent companies to foreign subsidiaries (USBEA, 2002). At the same time, trade liberalization reduced the tariff and non-tariff barriers of goods flow, decreased the trade discrimination, so that the multinational corporations could carry out freely products allocation and elements transfer, which not only reduced the costs but also further promoted the emergence and development of transnational corporations. Therefore, trade liberalization and multinational corporations were complementary. Trade liberalization was a prerequisite and basis for transnational corporations, accordingly, in order to obtain greater interests the multinational companies will strongly promote the international trade liberalization.

The increasing improvement of production internationalization promoted by multinational companies make one product to be completed in many countries, sometimes within a region can only complete one working procedure. The rules of origin affected the manufacturers and industries of certain procedure and different rules of origin with different stages of production were more closely integrated, which gave different effects.

\section{Insert Table 1 Here}

\subsection{FTA rules of origin improved the external level of protection and was a discriminatory trade tool}

The free trade area was a way to achieve trade liberalization of a country, in the free trade area, goods flew completely free, tariff and non-tariff barriers were zero, the external tariff level decided by the Member States. In accordance with the provisions of the WTO, the free trade areas needed to reduce the external tariffs while reducing internal trade barriers. The means of the external tariffs a region may choose were increasingly restricted, the rules of origin then become an effective way of protecting free trade area. The technicality of rules of origin was strong, which were easily to amend according to different products and countries, providing spaces for the realization of trade protection. Just as Bonade.Haldeman and Michael.KeStecchi said : "The liberalization of free trade agreements depended on its rules of origin." FTA rules of origin forced the regional manufacturers to use more components within the region, destroyed the optimal allocation of resources mode and improved the external level of protection. Implementation of open regionalism countries reduced not only internal tariff but also external tariffs, and gained economic benefits in international trade by trade conditions changes.

In addition, open regionalism was often a multilateral preferential principle (non-restrictive rules of origin), to ensure that member countries within the region get competitive intermediate inputs, reducing the costs of manufactured goods, increasing their international competitiveness. In the closed regional organizations, the rules of origin as the protection tool of non-tariff barriers, limited the imports of low cost raw materials outside the region, increased the costs of manufactured goods, and reduced their international competitiveness. For example, the South-North Trade Agreement rules of origin were stricter than the South-South agreements rules of origin (below). The EU and NAFTA rules of origin developed very detailed provisions according to the products varieties, technology processing, value-added size, although sometimes the rules of origin was for a specific link, can protect the entire production system. NAFTA existed a single value-added rules of origin principle for all products. Some economists verified the effect of North American Free Trade Area rules of origin, found that the use of higher local cost of intermediate inputs, leading to economy distortions which was equivalent to the results of $4.3 \%$ tariff. Open regionalism adopted non-restrictive rules of origin can import low-cost intermediate inputs outside of the region to produce exports, which reduced the cost of export products and increased overall competition force in world market.

The stricter of rules of origin, the higher degree of protection outside, showing it's discriminatory. The rules of origin was a discriminatory trade policy, mainly in the following areas: First, amendment of "non-fair trade". Second, protection of local industry. Third, rendering preferential to the developing countries, participating in multilateral trade, member countries of regional economic organizations. Fourth, for government procurement. Fifth, when the market opened up, as the preferential tools for market access. Sixth, policy for political interests expansion. In order to implement the correct anti-dumping measures directed at specific countries, the importing countries need to use reasonable rules of origin to determine the origin of imports. Thus in a certain degree, avoiding the circumvention. Similarly, the MFN treatment, government procurement and the correct implementation of safeguard measures can not do without the use of rules of origin. 


\subsection{FTA rules of origin promoted the internal mutual openness}

FTA rules of origin not only improved the external protection level, but also deepened the economic ties between member countries, and enhanced mutual openness. South-North Free Trade Agreement rules of origin were stricter than the South-South Free Trade Agreement leading to the South-North Free Trade Agreement with relatively higher internal openness. North American Free Trade Agreement was a typical representative of North-South free trade agreements, there were more than 200 pages of the rules of origin and both were very strict and complicated. Because of its complexity, the regional manufacturers used more production factors within the region and improved the efficiency and flexibility, promoted adequate exchanges of internal human and capital. The resulting series of related agreements such as the intellectual property, competition policy, and government procurement agreement contained in the North American Free Trade Area which were more perfect than other free trade agreements and agreements contained in the WTO. Multilateral trade agreements completed the agreements in accordance with the North American Free Trade Agreement order. Thus, the strict rules of origin can led to increased openness between member countries within the region and raised internal integration level.

But the South-South free trade agreements ran the opposite results. South -South free trade agreements with the non-restrictive rules of origin, the degrees of rigor were far below the North-South free trade agreements and the implementation of the results were far from ideal. Such as the Caribbean Community as well as the Eastern and Southern Africa Common Market effects were not obvious, with no strictly rules of origin protection within the member states, manufacturers adopted the principle of profit-maximizing to choose the lowest cost of raw materials, which could not intentionally support the internal related industries. Thus, the regional economic ties between member states became loose and internal integration was not improved, with mutual openness was limited too.

The strict rules of origin in South-North Free Trade Agreement promoted the expansion of intra-regional trade, and the trade creation effect was obvious, meanwhile, the expansion of merchandise trade not only promoting the development of services but also perfecting the intellectual property. That's why North America Free Trade Agreement contained a wide range of policies. So, be sure, strict rules of origin can promote the liberalization, openness and integration within the region.

However, the South-South Free Trade Agreement had a relaxed rules of origin, lowered the border costs, but the internal integration developed slowly. What's more, the implementation of the region can not guarantee results. But this approach was conducive to the development of global liberalization.

\section{References}

Bonade. Haldeman \& Michael. KeStecchi. (1999). The Political Economy of the world trading system - from GATT to the WTO, translated by Liu Ping, Hong Xiaodong \& Xu Mingde, etc.. Beijing: Law Press, 1999, p. 233.

OECD. (2001). Trade Blocks, pp.11, 28.

OECD. Regional and the Multilateral Trade System. Organization for Economic Co-operation and Development, p160.

World Bank Report. (2005). Global Economic Prospects, p. 70.

\section{Note}

Note 1. The data mainly from the World Bank's annual report. See: Global Economic Prospects 2005, World Bank Report, p.28. 
Table 1. Effects of different types of rules of origin on different production stages

\begin{tabular}{|c|c|c|c|c|}
\hline Basic rules & $\begin{array}{l}\text { Research and } \\
\text { development }\end{array}$ & Intermediate inputs & Final products & $\begin{array}{l}\text { Sales and } \\
\text { transportations }\end{array}$ \\
\hline $\begin{array}{l}\text { Substantive } \\
\text { processing }\end{array}$ & & $\begin{array}{l}\text { When the final } \\
\text { products need only } \\
\text { a simple processing }\end{array}$ & $\begin{array}{l}\text { Working usually } \\
\text { when the final } \\
\text { products non-simple } \\
\text { assembly }\end{array}$ & \\
\hline $\begin{array}{c}\text { specific } \\
\text { manufacturing } \\
\text { processes based on } \\
\text { high-tech }\end{array}$ & $\begin{array}{l}\text { The key program or } \\
\text { major components } \\
\text { related to research } \\
\text { and development }\end{array}$ & & & \\
\hline $\begin{array}{c}\text { Rules of origin } \\
\text { contain investment } \\
\text { inputs }\end{array}$ & $\begin{array}{l}\text { Machine containing } \\
\text { intellectual } \\
\text { property, research } \\
\text { and development }\end{array}$ & & & \\
\hline Value-added criteria & $\begin{array}{c}\text { Research and } \\
\text { development } \\
\text { contain a small } \\
\text { percentage of the } \\
\text { final product value }\end{array}$ & $\begin{array}{l}\text { When calculating } \\
\text { value added, the } \\
\text { individual parts can } \\
\text { play a key role }\end{array}$ & $\begin{array}{l}\text { Most of the value } \\
\text { are achieved at this } \\
\text { stage, but does not } \\
\text { consider the sale } \\
\text { and transport }\end{array}$ & $\begin{array}{c}\text { Sales and } \\
\text { transportations can } \\
\text { constitute most of } \\
\text { the value-added }\end{array}$ \\
\hline
\end{tabular}

Source: Edwin Vermulst, Paul Water, and Jacques Bourgeois: Rules of Origin in International Trade: A Comparative Study, The University of Michigan Press, 1997, pp25.

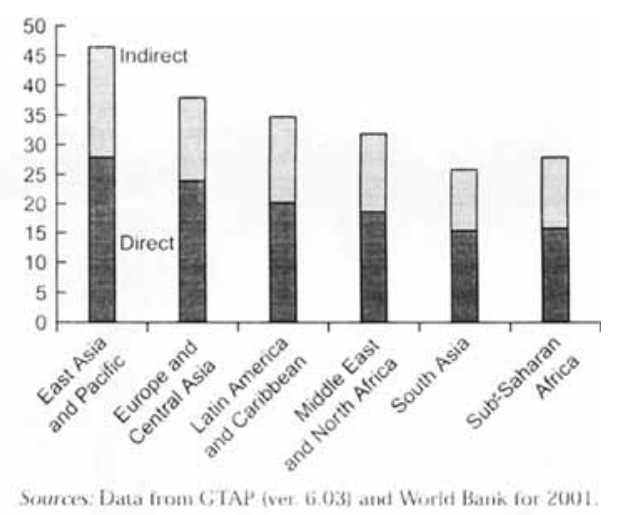

Figure 1. The share of vertical integration in the global economy

Note: In figure 1, the vertical axis represents the proportion of imports to exports, the horizontal axis represents the following region: East Asia and Pacific, Europe and Central Asia, Latin America and the Caribbean, Middle East and North Africa, South Asia, Sub-Saharan Africa. 


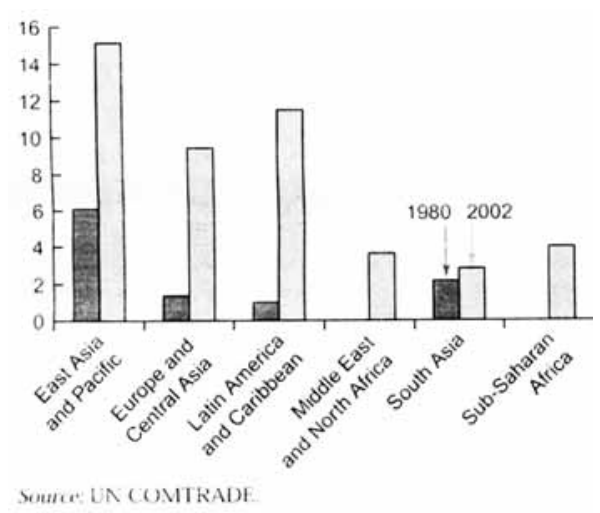

Figure 2. The share of intermediate inputs in the regional trade

Note: In figure 2, vertical axis represents the share of parts of the export in total exports, the horizontal axis represents regions as fig 1 .

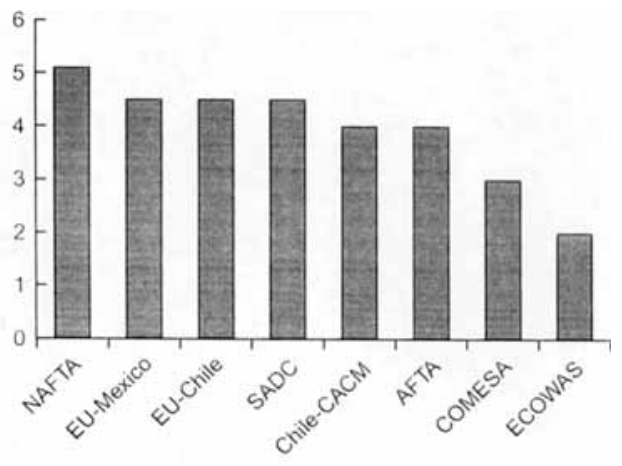

Note: Higher values of the index equal more restrictive rules of origin lderived from Estevadeordal and Suominen

Figure 3. The stringent degree of South - North Trade Agreement rules of origin relative to the South - South trade agreements

Note: vertical axis represents the restriction index 